something that will stay by them", and for this "we have to sacrifice things we think valuable". Surely the end which is desired makes this worth while.

In the discussion on general science which followed, the question of the teaching of general science by one mistress and as one subject, and not by individual specialists, was raised. Some members felt that in the two years preceding School Certificate the syllabus should be taught by specialists in the individual branches. The majority of the members present appeared to consider that more was gained when it is taught by one, and that freshness of outlook, saving of time and greater correlation between the branches might result.

Miss Casswell, headmistress of the Edgbaston High School for Girls, gave an interesting report on the minimum syllabus for general science, which is based on the minimum syllabus of the Association of Assistant Mistresses and of the Association of Women Science Teachers, and on the extended syllabus which is based on the Science Masters' Association's Report on General Science, Part 2. Both of these new syllabuses have been drawn up by the Joint Matriculation Board of the Northern Universities. The minimum syllabus does not have a bias in any particular direction, and it tries to get a unity of science through a study of forms of energy, the material environment and the plants and animals of the environment. The syllabus is such that in ordinary circumstances there should be time for revision and for the introduction of other material which will give the individual teachers freedom of choice. The second paper naturally requires more time, and there would necessarily be opportunity for greater selection and deeper study of sections of the syllabus in which there might be greater interest, and this would involve effort to suit the work to the special circumstances and environment of the school.

Throughout the meeting it could be seen that there was a real and deep appreciation by science teachers of the need to make the teaching such that "it should reveal the influence of scientific thought and achievement in the evolution of our present-day civilisation, and that it should indicate its possibilities, for good and evil, in the future of the human race".

\title{
Petroleum and World Politics
}

\begin{abstract}
THE importance of the geographical distribution of the heavy minerals around the North and South Atlantic Oceans was stressed in Nature of January 28, p. 169 . It is well to remember, however, that the world distribution of petroleum is also closely related both to the arts of peace and to the horrors of modern warfare. In the present temper of the world, any non-belligerent nation which possesses reserves of petroleum is in danger of finding itself involved in serious political complications. This is especially true of those States of South America which are believed to possess the world's largest reserves of petroleum. In this connexion, some remarks of Dr. D. Rey Vercesi and Dr. Juan H. Caorsi of Montevideo, in a paper of recent date $^{1}$, seem worthy of wider attention.

The authors observe that it is the policy of the more advanced nations of the world to exploit for their own prineipal benefit the supplies of petroleum in the less-advanced countries of South America. Since 1936 , also, it has become the policy of the United States, which is the largest producer as well as the largest consumer of petroleum, to conserve its own resources, which are calculated to be sufficient for about thirty years at the present rate of consumption, and to import large quantities of crude oil from foreign, mainly South American, sources. This attitude of the greater Powers is causing much searching of heart among South American peoples, who see their national resources being rapidly depleted and perhaps to some extent wasted elsewhere in the frantic rush of the modern world. Such stirrings of national spirit help to explain the recent happenings in Mexico and other States.

The authors place the world production of crude oil in 1937 at about two thousand million barrels, and give the following figures of production in the principal producing countries in thousands of barrels (each barrel $=42$ gall.)
\end{abstract}

$\begin{array}{lrrllll}\text { U.S.A. .. } & \ldots & 1,278,000 & \text { Mexico } & \ldots & \ldots & \mathbf{4 6 , 7 0 0} \\ \text { U.S.S.R. } & \ldots & 200,000 & \text { Iraq } & . & \ldots & \mathbf{3 0 , 7 0 0} \\ \text { Venezuela } & \ldots & 185,300 & \text { Colombia } & & \ldots & 20,200 \\ \text { Iran } & \ldots & 78,100 & \text { Peru } & . . & \ldots & \mathbf{1 7 , 7 0 0} \\ \text { Dutch Indies } & \ldots & \mathbf{5 4 , 9 0 0} & \text { Trinidad } & . & \ldots & \mathbf{1 5 , 6 0 0} \\ \text { Rumania } & \ldots & \mathbf{5 2 , 0 0 0} & \text { Argentine } & & \ldots & \mathbf{1 5 , 3 0 0}\end{array}$

They quote General Serrigny's recent estimate in round figures of exportation in tons from the four principal geographical producing regions :

$$
\begin{aligned}
& \begin{array}{llll}
\text { North America } & \ldots & \ldots & 21,000,000 \\
\text { South America } & . & \text {. } & 28,000,000 \\
\text { East Mediterranean } & & \text {. } & 12,000,000
\end{array} \\
& \begin{array}{lll}
\text { East Mediterranean } & \ldots & 12,000,000 \\
\text { Orient } & \text {.. } & 14,000,000
\end{array} \\
& \text { Total _. } \overline{75,000,000}
\end{aligned}
$$

Of this total, about 33 million tons go to Europe.

The authors remark that since the necessities of a European war in which the United States might be involved would greatly increase the demand for petroleum and the non-belligerent countries would not diminish their consumption, it would be necessary to increase world production perhaps two or three times, and supposing that supplies from North America, the east Mediterranean and the Orient were for various reasons unobtainable or unreliable, on South America would fall from necessity or choice the principal charge of meeting the increased demand. The South American States, and especially Venezuela and Colombia, would thus be required to supply the demands of the belligerents.

It is clear that an international situation of great gravity might easily arise, and it is good to know that the younger and clearer minds in South America are already at work upon the problem. The authors urge the necessity of co-operation between the South American States themselves and collaboration in a spirit of peace and good will with the industrialized nations of the world for the general good of humanity. J. D. Falconer.

1 "Politica del Petroleo a seguirse por los paises sudamericanos". A.N.C.A.P., Montevideo, 1938. 